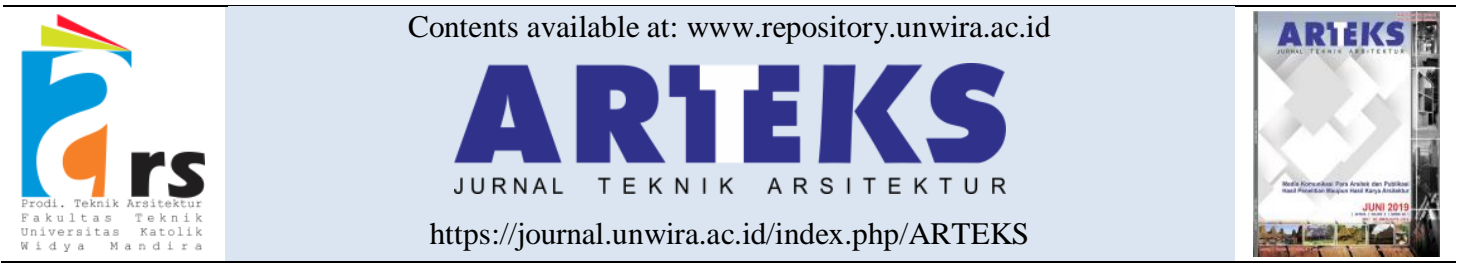

Research paper

doi: 10.30822/arteks.v5i3.599

\title{
Physical form sustainability of Huta Siallagan Samosir architecture in supporting Toba Caldera Geopark Cultural Tourism
}

\section{Rumiati Rosaline Tobing*(D), Andi Kumala Sakti, Hanny}

Research and Community Service Institute,

Department of Architecture, Faculty of Engineering, Universitas Katolik Parahyangan

Jl. Ciumbuleuit, no. 94, Bandung, Indonesia

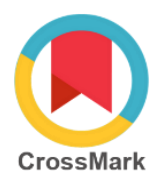

\begin{tabular}{|c|c|}
\hline ARTICLE INFO & ABSTRACT \\
\hline $\begin{array}{l}\text { Article history: } \\
\text { Received July 04, } 2020 \\
\text { Received in revised form July } 242020 \\
\text { Accepted September 17, } 2020 \\
\text { Available online December 01, } 2020\end{array}$ & $\begin{array}{l}\text { Toba Lake is one of Indonesia's most priority destinations included } \\
\text { in the UNESCO Global Geopark. This makes it increasingly famous, } \\
\text { necessitating its continued maintenance and preservation. Tourism } \\
\text { is one of the economic sources of revenue in Indonesia. Since } 2019 \text {, } \\
\text { the government is determined to increase revenue from the tourism }\end{array}$ \\
\hline $\begin{array}{l}\text { *Corresponding author: Rumiati Rosaline } \\
\text { Tobing } \\
\text { Department of Architecture, } \\
\text { Faculty of Engineering, } \\
\text { Universitas Katolik Parahyangan, Indonesia } \\
\text { Email: rumi@ unpar.ac.id } \\
\text { ORCID: 0000-0002-7771-3610 }\end{array}$ & $\begin{array}{l}\text { priority destinations influences environmental and socio-cultural } \\
\text { maintenance and provides economic opportunities to local tourism } \\
\text { village communities. The Huta Siallagan area of Samosir Regency } \\
\text { is a village known for the beginning of the law enforcement } \\
\text { civilization in Samosir. This tourist village has a stone trials site } \\
\text { aged about } 500 \text { years, as one of the cultural attractions. The Stone } \\
\text { Trial has been maintained for hundreds of years, becoming an } \\
\text { interest to tourists, and one of the historical sites included in the } \\
\text { Toba Caldera Geopark's geo- site. As a result, its sustainability } \\
\text { needs to be maintained. The Samosir Regency Government is } \\
\text { implementing the sustainability of tourism. This study showed a } \\
\text { survival aspect from an architectural viewpoint, reflected in the form } \\
\text { of Huta Siallagan. The study aimed to determine the survival value } \\
\text { in Huta Siallagan. A case study was used to explore architecture, } \\
\text { tradition and life due to society's cultural aspects. }\end{array}$ \\
\hline
\end{tabular}

\section{Introduction}

Toba Lake is one of Indonesia's super-priority destinations officially included in the UNESCO list (Antara and Wuragil 2020). This makes it increasingly famous, necessitating continued preservation. The July 2019 survey showed that $63 \%$ of global tourists prefer sustainable tourism (Thakkar 2019). This affects environmental, social, and cultural maintenance and provides economic opportunities for local tourism village communities (Purbadi and Lake 2019; Budihardjo 2019). Samosir, also known as Tourist Village, is an island crowded with tourists. The island has several villages, such as Tuktuk Siadong, which has adequate infrastructure. About 3 kilometers from the Tuktuk village, there is Huta Siallagan, a historic stone trial site, which is one of the geosites in Toba Caldera Geopark. It is known as the beginning of law enforcement civilization in Samosir, eventually becoming a cultural tourism village (Hanny 2020). A social system also supported huta Siallagan through bonding force to the Toba Batak tribe (Hutabarat 2019). Conversely, the formation of the traditional Batak Toba settlements was based on the philosophy of dadap na tolu (Tobing and Hutabarat 2019) and cosmological thinking in the formation of jabu bolon and sopo dwellings (Sudarwani and Priyoga 2019; Siahaan 2017). The study object is the sustainable architecture found in Huta Siallagan's physical formation. It results from an architectural 
assessment that meets current needs without harming the future generations' ability to meet their needs, which differ between communities (Tobing, Sakti, and Hanny 2020). Munasinghe (2007) stated that sustainable development is supported by environmental, economic, and social aspects (Munasinghe 2007). They are interconnected, supporting one another as the basic principles of sustainable architecture. These 3 aspects are important in shaping sustainable architecture in Huta Siallagan, a traditional Batak Toba settlement (see figure 1).

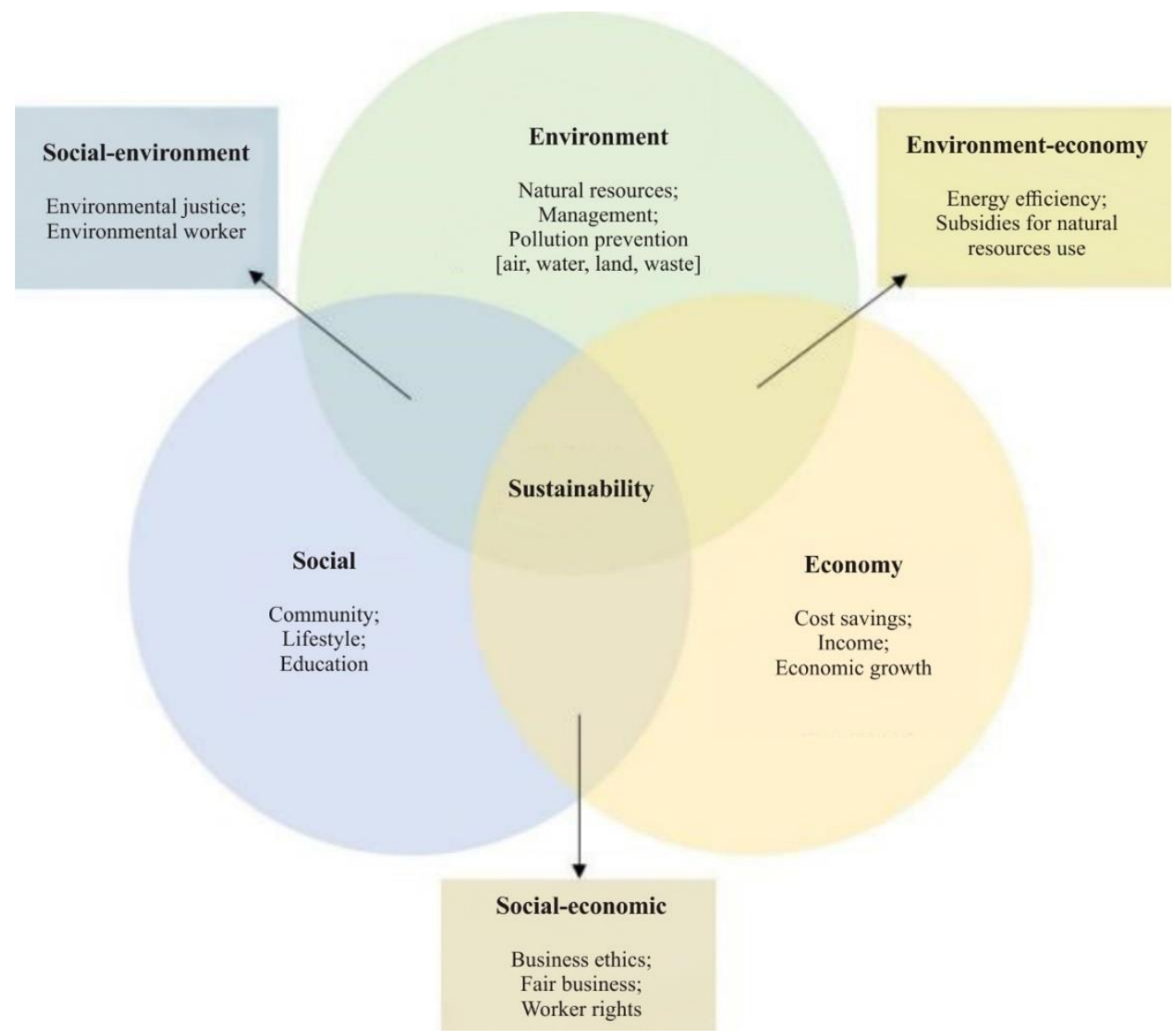

Figure 1. The 3 main aspects of sustainability

Source: (Munasinghe 2007)

\section{Sustainable architecture}

The existence of a trial stone site and a traditional settlement of Huta Siallagan can be maintained. This study determines the position of Huta Siallagan based on sustainable architectural values. The research findings are useful to the Samosir Regency government in supporting the existence of Huta Siallagan as a geo-site from Unesco Global Geopark Toba Caldera. Furthermore, they provide information about sustainable architecture as a novelty in this study.

In this study, the sustainable architecture concept comprises several interconnected and comprehensive aspects. Therefore, the parameters needed in this assessment, include:
1) Society;

2) The part outside the house;

3) The part inside the house;

4) Building components;

5) Building material;

6) Natural resources;

7) Waste treatment;

8) Financing.

Each element is valuable enough to show the overall condition of the architectural physical form of the settlement area and the supporting aspects are in a position of sustainable architecture (Larasati 2007; Widodo 2019; Subroto 2019). 
Toba Batak settlement concept

The formation of the Toba Batak settlement is closely related to a clan. This is because a clan is very important in the Toba Batak tribe, especially in terms of the settlement area's compaction and zoning (Tobing and Hutabarat 2019). Conversely, the traditional Toba Batak building also applies the concept of cosmology. This is apparent in the principle of philosophically dividing residential buildings into Banua Ginjang, the roof part of house symbolizing the Almighty, Banua Tonga, the body part of the building, symbolizing the place of humans, and Banua Toru, the foot part of the building, symbolizing the place of death (Schefold, Domenig, and Nas 2004), as shown in figure 2.

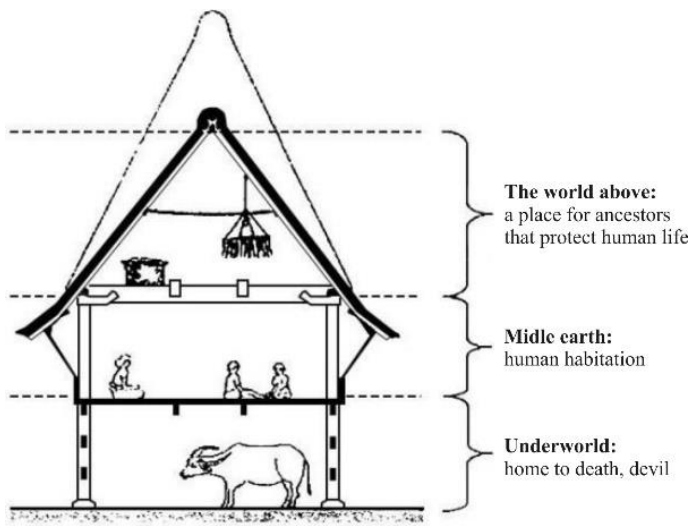

Figure 2. The concept of cosmology in the Toba Batak residential building

Source: (Setiawan 2019)

In the settlement area, there are several jabu following the needs of the clan. Also, there are sopo as open buildings, commonly used for storage and ulos cloth weaving activities in a shared lifestyle.

Jabu and Sopo buildings are arranged in 2 directions. The Sopo building functions as a rice granary. Sopo and jabu are arranged to face each other, with the sopo building placed opposite jabu to facilitate supervision (Tobing and Hutabarat 2019). The Toba Batak settlement environment is a village traditionally called Huta (T. Setiawan 2010), as shown in figure 3.

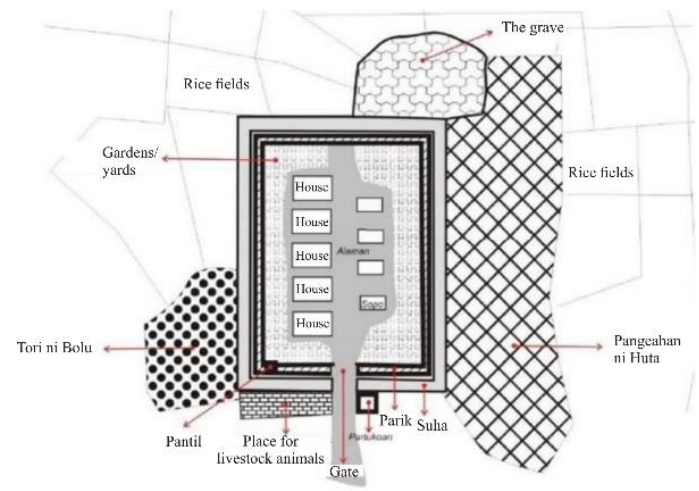

Figure 3. The concept of traditional Toba Batak settlement

Source: (T. Setiawan 2010)

According to Christian Norberg-Schulz (1963), the formation of traditional Toba Batak settlements is the grouping of cultural symbols through human architectural works to meet the needs of each activity, reflecting the values of society in everyday life (Norberg Schulz 1965, 122).

The architectural work is the soul of a culture, evidenced by the spatial space and physical structure (Norberg-Schulz 1991). John Hendrix (2012) stated that the architectural work is an expression and form of communicating ideas, values (Hendrix 2012). Furthermore, it is a product of the adopted cultural results, reflecting the relationship between cultural and functional aspects.

\section{Method}

This study focused on sustainable architecture in the physical formations of Huta Siallagan. A case study method was used with a qualitative approach. The research phase began with studying sustainable architectural concepts, and the formulation of the following research questions:

1) What are the values of sustainable architecture found in the traditional settlement of Huta Siallagan?

2) How is architecture's sustainability in the traditional settlement of Huta Siallagan as a tourist site and destination?

Through these questions, data collection and analysis were related to the research focus. The results describe all events, conditions, and circumstances related to the search for sustainable architectural values from the case study on Huta 
Siallagan, a cultural tourism village. The location is in Ambarita Village, Simanindo District, Samosir Regency, North Sumatera. Before observations and data collection, a literature review was conducted on the concept of sustainable architecture, Batak Toba traditional tribes, and cultural tourism. The data collected was based on environmental, social, and economic aspects of sustainable architecture and traditional Batak Toba settlements. The data was collected through in-depth observations, interviews, discussions, and documentation, based on sustainable architecture aspects in Huta Siallagan as a traditional Batak Toba settlement.

The data were analyzed on the eighth element parameters by the DCBA method. Quality values of Huta Siallagan were classified into level D, a normal situation, level $\mathrm{C}$, the right use, level $\mathrm{B}$, a condition that minimizes environmental damage, and level A, the ideal situation. Based on this level, a description related to the sustainable architectural value of Huta Siallagan as cultural tourism was found. The study was conducted from August 2019 to May 2020.

Case study

Data of Huta Siallagan village was administratively located in North Sumatera Province, Samosir Regency, Simanindo Subdistrict, Huta Siallagan Village, Pinda Raya, Hamlet II. It has an area of $3.1 \mathrm{~km}^{2}$ and a population of 700 inhabitants (figure 4).
The location of Huta Siallagan is illustrated in figure 4 .

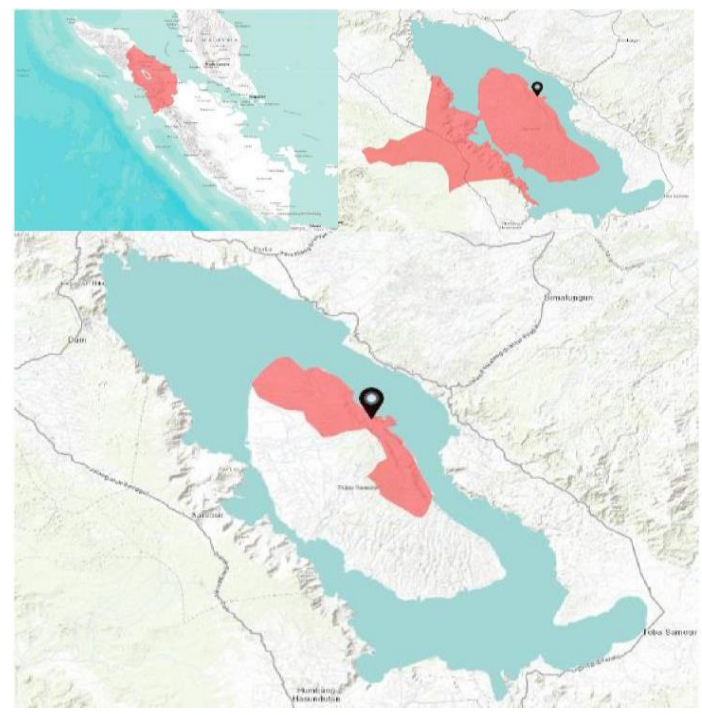

Nort Sumatera Province; Samosir Regency; Huta Siallagan Village

Figure 4. Huta Siallagan location

Source: (Tobing, Sakti, and Hanny 2020)

\section{Result and discussion}

The research analysis framework is illustrated in figure 5 .

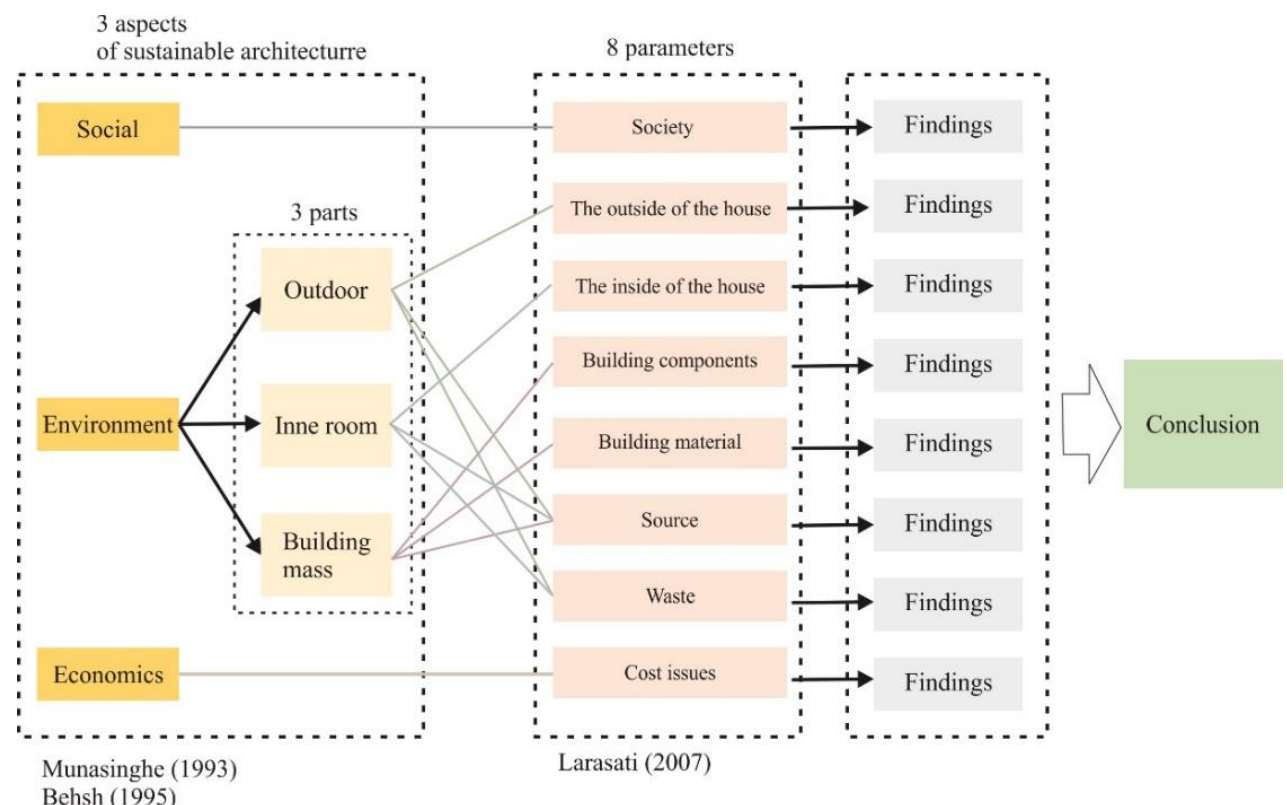

Figure 5. Analysis framework 


\section{Social or society}

Relations exist between communities in the neighboring context because of the Siallagan clan power that adheres to the traditional Batak Toba settlement concept, referring to one Huta with one dominant clan, and family relations. It was strengthened by the intermediate spaces as a place for people to interact. Jabu's placement scheme, based on family relationships, is illustrated in figure 6 .
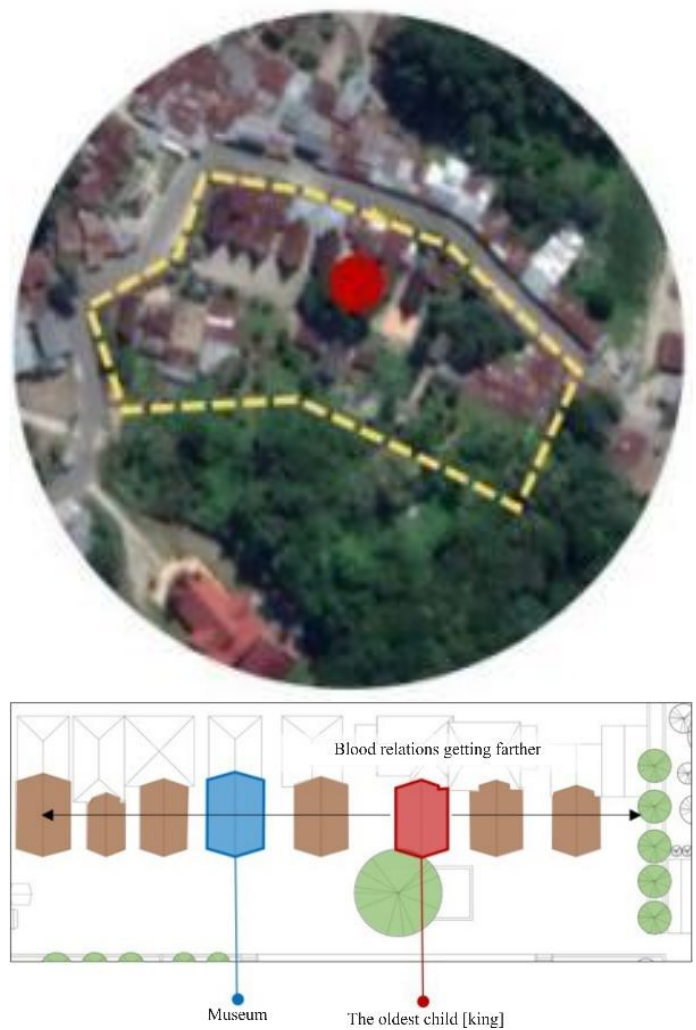

Figure 6. Occupants Huta Siallagan and family relations

Source: (Tobing, Sakti, and Hanny 2020)

As a cultural tourism village, the Huta Siallagan community strives to increase awareness and maintain its tradition. The role of the community is a power for the potential of cultural sustainability. The community involvement scheme is illustrated in figure 7.

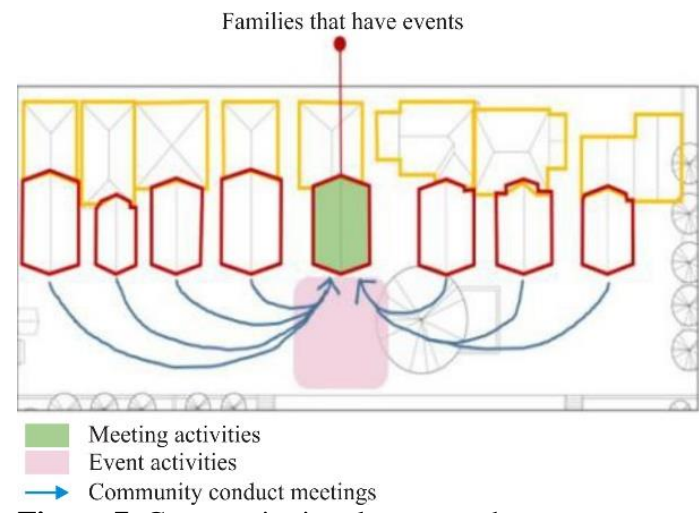

Figure 7. Community involvement scheme

Source: (Tobing, Sakti, and Hanny 2020)

Coordination of tourism activities is carried out through an agreement in the task distribution between communities. Although it appears quite good, it is a weakness that should be considered. This is because they have to educate the next generation in order to be sustainable and survive. Furthermore, innovation should be sought for cultural tourism development. The Huta Siallagan environment's cleanliness is well maintained by all communities, setting an example for the surrounding villages to produce high sustainable value. Public transportation is currently available in the form of cars and pedicabs. This facilitates the faster movement of tourists in reaching Huta Siallagan and other facilities and infrastructure around it. The accessibility supports the survival of this area as cultural tourism. The transportation pattern is illustrated in figure 8 .

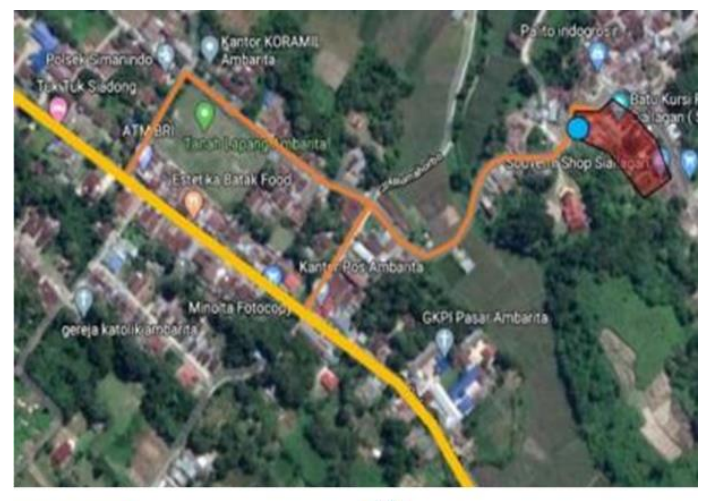

Samosir Island road $\bigcirc$ Pedi cap base
Path to the main road

Figure 8. Public transportation patterns Source: (Tobing, Sakti, and Hanny 2020)

\section{Part outside the house}

Important outdoor space at Huta Siallagan is the area between building houses used as a 
circulation area and a place to conduct joint activities. Activities that support cultural tourism are also carried out in the open space. It is illustrated in figure 9.

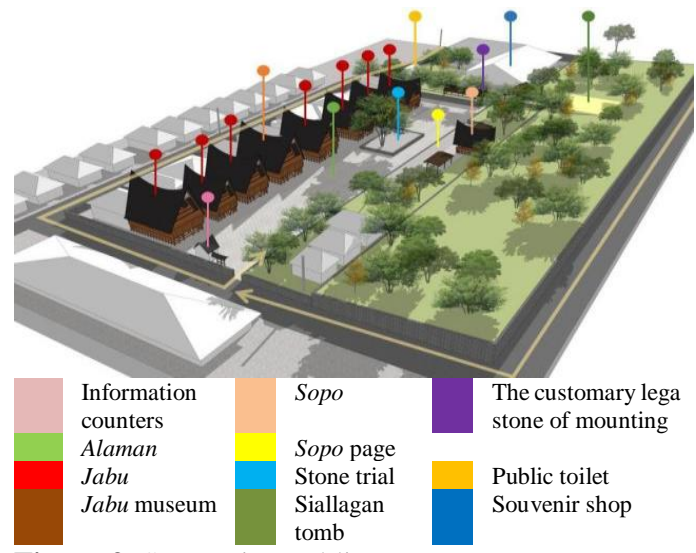

Figure 9. Supporting public space

Cultural tourism experienced by visitors and supports in outdoor spaces includes the trial stone site, a historical heritage that signifies customary law exercised by the king.

Alaman is a place where visitors are invited to dance tortor as a traditional Batak tribe dance. The customary law stone area tells the history of the criminal's punishment by the king and the tomb of King Siallagan. Furthermore, it was continued with the souvenirs selling area of Batak Toba typical as a memento. Based on the assessment results of sustainable elements, public space in Huta Siallagan is in a level A position, accommodating various activities and supporting cultural tourism villages' sustainability, as shown in figure 10.

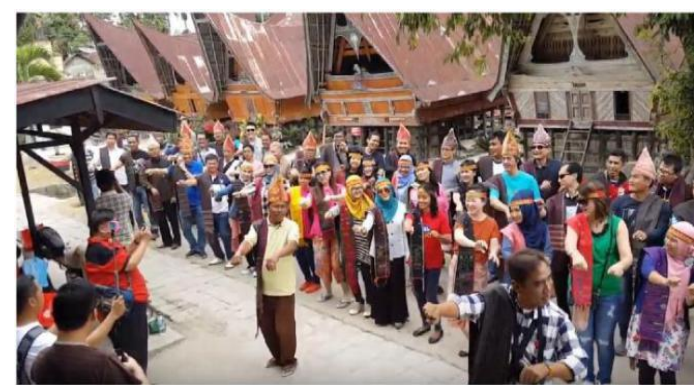

Figure 10. Traditional cultural tourism in alaman as a public space

\section{Part Inside the House}

The house building consists of jabu building as a residence in a traditional form and additional modern buildings (figure 11).

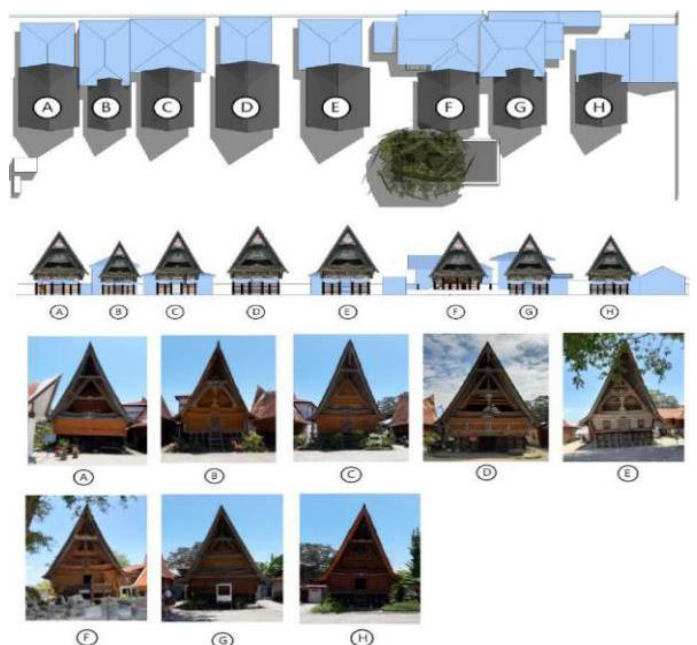

A, B, C, King Siallagan's traditional family homes $\mathrm{G}$, and $\mathrm{H}$

D The traditional house used as a museum

E The traditional house of King Siallagan's bodyguards

F Raja ni Huta Siallagan's house

Modern housing as an extension of each Jabu Bolon traditional house

Figure 11. Type of residental building

Source: (Tobing and Purnamasari 2019)

The inner house layout is formed based on concepts passed down from generation to generation. Implementing the ventilation and natural lighting concept is seen as an assessment of the sustainability conditions from the part inside the house. It is illustrated in figure 12 .

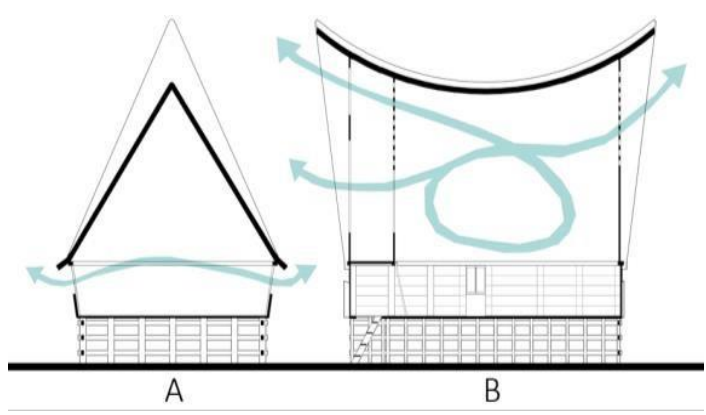

Figure 12. Ventilation in residental

Source: (Tobing, Sakti, and Hanny 2020)

Natural ventilation is supported by the placement pattern between building houses with a distance and the shape of a high roof, facilitating the free flow. The zoning in the house creates a clear division between public and private space, maintaining sustainable architectural value. It is illustrated in figure 13 . 


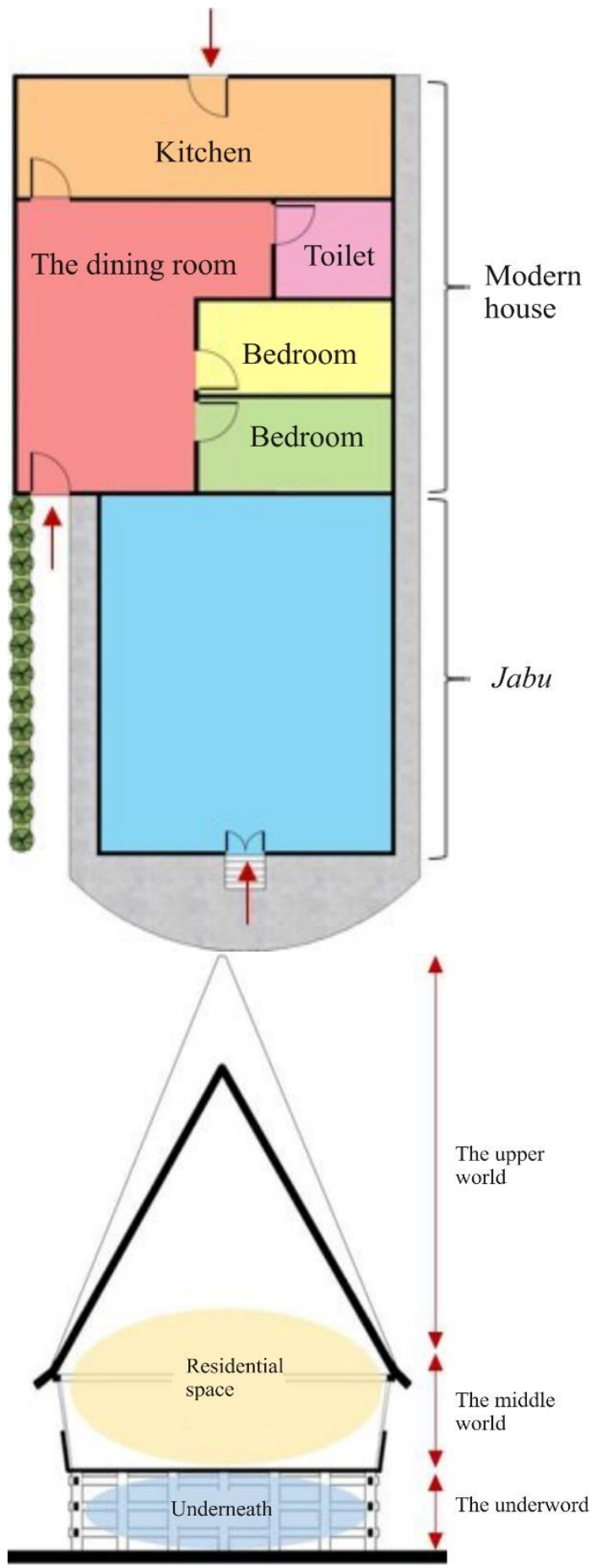

Figure 13. The space zoning in horizontal and vertical Source: (Tobing, Sakti, and Hanny 2020)

4 Building components

Based on the conducted assessment, the building process at Huta Siallagan is sustainable due to the simple techniques passed down from generation to generation. By the use of simple equipment, the building is usually performed by all residents through cooperation. However, there are no standards for building components, which is to be considered in the future. The material formation is one of the maintained factors. It is illustrated in figure 14 .

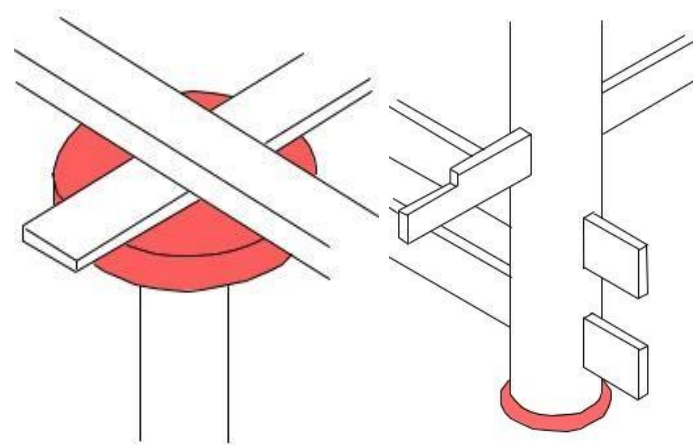

Figure 14. The technique of piercing wood without nails

Source: (E. Setiawan and Tobing 2019)

\section{Building material}

The building materials of the foundation on jabu and sopo consist of stone and wood obtained locally. They are, therefore, durable and have a sustainable value. The walls consist of wood from trees such as coleus and ariara, collected from around Huta Siallagan by replanting.

In the past, the roofs of jabu and sopo buildings were made of wooden structures and palm fiber covers. However, the buildings are currently roofed using zinc material that is easier to procure than the palm fiber that is almost extinct, as shown in figure 15 .

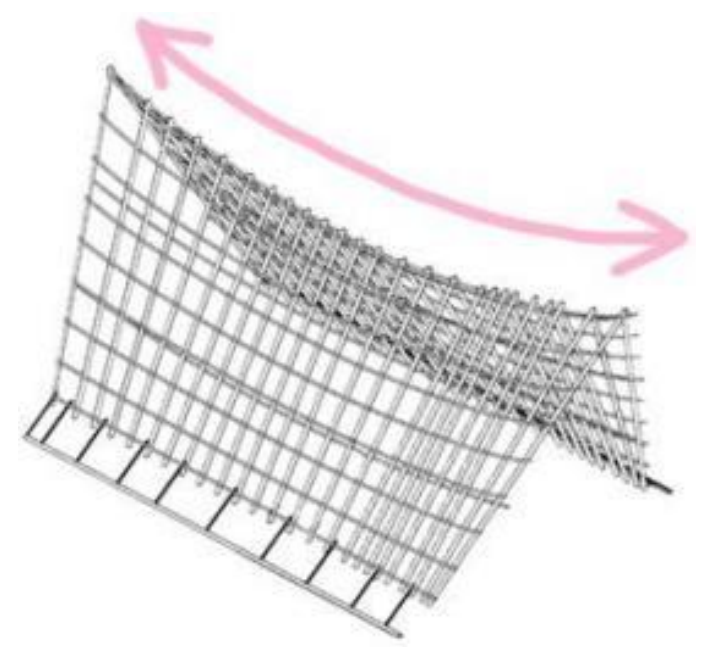




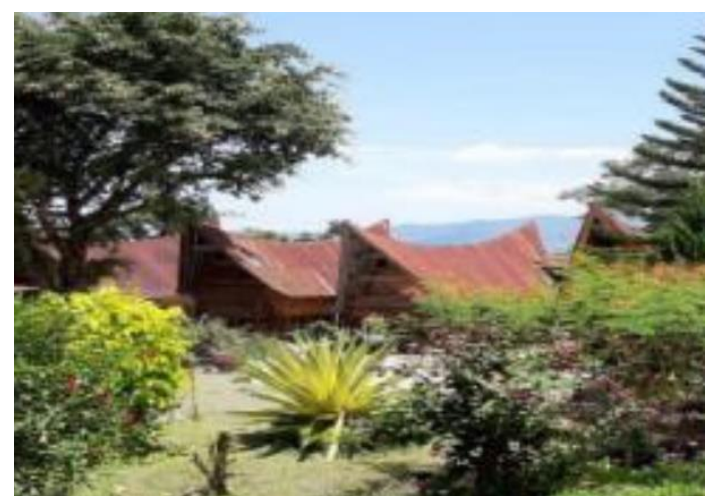

Figure 15. Wood and zinc as the cover material of house buildings

Source: (Tobing, Sakti, and Hanny 2020)

\section{Source}

The resources used by the Huta Siallagan society to lead a sustainable life include wood building materials from local forests, stones from the surrounding environment, clean water from wells, groundwater, and electricity from the State Electricity Company/Perusahaan Listrik Negara (PLN). The assessment of sustainable architecture based on resources is adequately good, due to the community's frugal use of electricity. This is further supported the utilization of groundwater through the artesian well, and clean water from the Regional Water Supply Company. The community has the potential to support sustainable water supply, supported by fertile agricultural land conditions, as shown in figure 16.

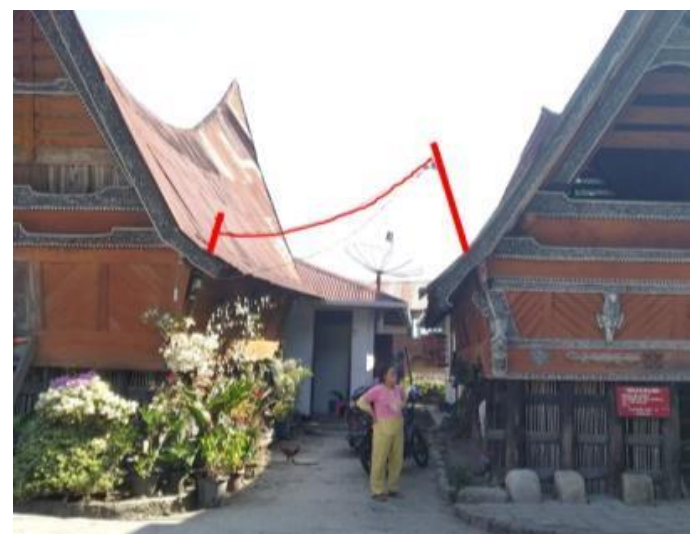

Figure 16. The distribution of electricity as a support for cultural tourism activities

Source: (E. Setiawan and Tobing 2019)

\section{Waste Management}

The wastewater management scheme is facilitated by drainage into sewers and septic tanks. From the existing conditions, the assessment of sustainable architectural support has not been fulfilled because the wastewater from the washing place has not been recycled. Besides, household waste management is still exercised conventionally. Therefore, it has not reached the optimal sustainable architectural value because the society has not sorted organic and non-organic household waste to achieve environmental values with minimal pollution, by executing a recycling system. It was concluded that the Huta Siallagan Society does not know the waste recycling system.

\section{Financing}

In the financing of the construction and maintenance of jabu and sopo buildings in Huta Siallagan, the society receives assistance from the Samosir Regency government. Therefore, they sustainably conduct cultural tourism activities, especially in keeping and maintaining the strength and beauty of the buildings' elements and their cleanliness. This is seen in figure 17.

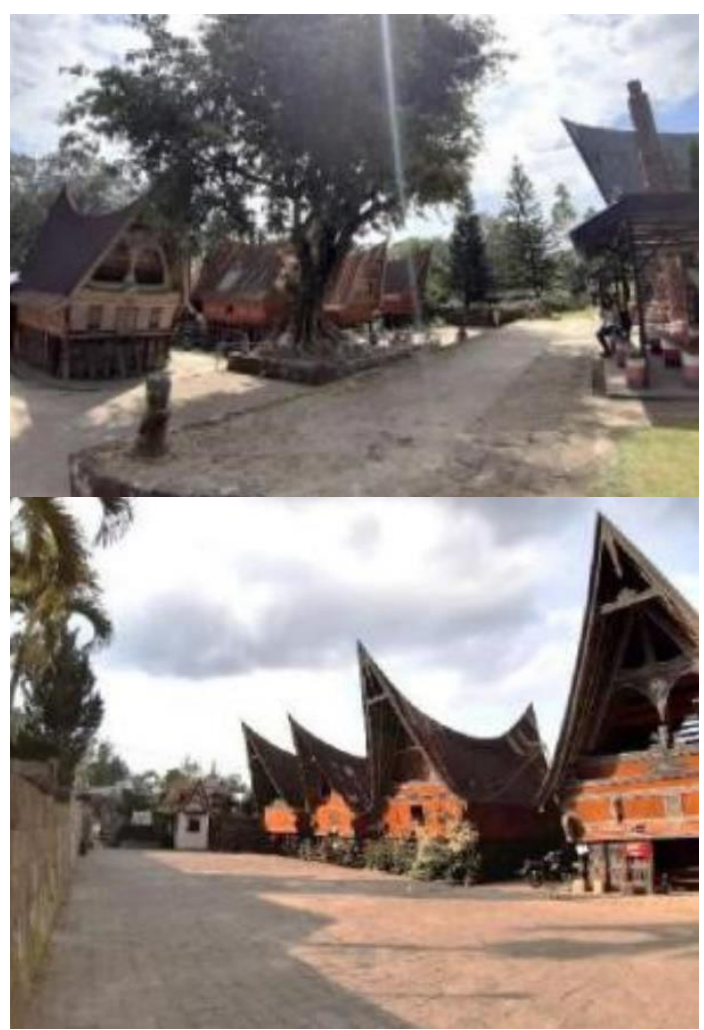

Figure 17. The physical appearance of Huta Siallagan cultural tourism village

Source: (Tobing, Sakti, and Hanny 2020) 
The entire Huta Siallagan society overcomes the problem of funding in managing cultural tourism villages through the division of tasks in tourists' service and the distribution of areas to engage in income-generating activities. These include historical tours, tortor traditional dances, stories and history demonstration of past judgments, the sale of souvenirs 1 of the Toba Batak Tribe.

A summary of the sustainable architecture assessment based on the 8 elements in Huta Siallagan is in table 1 below.

Table 1. Summary of findings from the value of sustainable architecture

\begin{tabular}{|c|c|c|c|c|c|}
\hline No & Value & D & C & B & $\mathbf{A}$ \\
\hline \multirow[t]{9}{*}{1} & Society & & & & \\
\hline & Neighborhood & & & & \\
\hline & Involvement & & & & \\
\hline & Mutual cooperation & & & & \\
\hline & Social activities & & & & \\
\hline & Initiative & & & & \\
\hline & Solid waste & & & & \\
\hline & Drinking water & & & & \\
\hline & Facilities and services & & & & \\
\hline \multirow[t]{4}{*}{2} & Part outside the house & & & & \\
\hline & Public space & & & & \\
\hline & Yard and garden & & & & \\
\hline & Building expansion & & & & \\
\hline \multirow[t]{5}{*}{3} & Part Inside the House & & & & \\
\hline & Inner Space & & & & \\
\hline & Lighting & & & & \\
\hline & Ventilation & & & & \\
\hline & Noise and air pollution & & & & \\
\hline \multirow[t]{4}{*}{4} & Building components & & & & \\
\hline & Building process & & & & \\
\hline & Dimension & & & & \\
\hline & Durability and maintenance & & & & \\
\hline \multirow[t]{5}{*}{5} & Building material & & & & \\
\hline & Foundation & & & & \\
\hline & Wall & & & & \\
\hline & Structure & & & & \\
\hline & Roof & & & & \\
\hline \multirow[t]{5}{*}{6} & Source & & & & \\
\hline & Material & & & & \\
\hline & Energy & & & & \\
\hline & Clean water & & & & \\
\hline & Drinking water & & & & \\
\hline \multirow[t]{4}{*}{7} & Waste & & & & \\
\hline & Dirty water & & & & \\
\hline & Household & & & & \\
\hline & Rubbish & & & & \\
\hline \multirow[t]{4}{*}{8} & Financing & & & & \\
\hline & Building & & & & \\
\hline & Energy & & & & \\
\hline & Production house & & & & \\
\hline
\end{tabular}

\section{Conclusion}

The value of the Huta Siallagan is shown in table 1. Huta Siallagan is at an A grade and is ideal for meeting the sustainable architecture. However, there are weaknesses in the elements of waste management and financing, which are at the $\mathrm{C}$ and $\mathrm{D}$ values level.

Based on social elements' parameters, Huta Siallagan is at the level of A values based on culture compaction, mutual understanding, and society involvement in activities as a cultural tourism village. This enables the community to continuously fulfill sustainable architecture. From the building element, the quite good value is the basis for sustainable architecture. Based on the element of resources, the society has not mastered the knowledge and technology to effectively and efficiently utilize and manage the water resources. This condition should be overcome through the local government and other institutions' assistance by providing knowledge and technology.

Furthermore, society needs to be continuously motivated into the next generation to continue to fulfill sustainable architecture and produce qualified areas as cultural tourism villages. Including in developing and learning the necessary knowledge and technology and understanding that Huta Siallagan must be maintained and preserved as a cultural tourism village, due to it can be a potential for society to improve the standard of living in terms of economy, history, and culture. Besides, the village and district governments need to support the existence of Huta Siallagan continuously.

\section{Acknowledgement}

The authors express gratitude to the Parahyangan Catholic University Research and Community Service Institute/Lembaga Penelitian dan Pengabdian kepada Masyarakat (LPPM), the extended family of the Siallagan clan through the spokesperson, Mr. Bagus Siallagan, for his kindness, acceptance, and support in helping this research. The research team also thanked the ARTEKS : Jurnal Teknik Arsitektur editorial team for publishing this article. 


\section{References}

Antara, and Zacharias Wuragil. 2020. 'Danau Toba Ditetapkan Sebagai UNESCO Global Geopark'. Tempo.Com. 2020.

Budihardjo, Rachmat. 2019. 'Pengaruh Pariwisata Pada Adaptasi Fungsi, Bentuk Dan Ruang Arsitektur Puri, Studi Kasus: Puri Saren Agung Ubud'. ARTEKS : Jurnal Teknik Arsitektur 4 (1): 63-72. https://doi.org/10.30822/arteks.v4i1.80.

Hanny. 2020. 'Kajian Arsitektur Berkelanjutan Pada Kawasan Permukiman Tradisional Huta Siallagan, Samosir, Sumatera Utara'. Bandung.

Hendrix, John. 2012. The Cultural Role of Architecture. Edited by Paul Emmons, Jane Lomholt, and John Shannon Hendrix. The Cultural Role of Architecture: Contemporary and Historical Perspectives. Routledge. https://doi.org/10.4324/9780203723777.

Hutabarat, Grace Mananda. 2019. 'Relation Between Physical Spatial Order of Settlement With Batak Toba Society'S Kin Relationship Study Object: Huta Ginjang Village, Sianjur Mula-Mula Sub-District'. Riset Arsitektur (RISA) 3 (03): $277-94$. https://doi.org/10.26593/risa.v3i03.3336.277294.

Larasati, Dwinita. 2007. 'Towards an Integral Approach of Sustainable Housing in Indonesia: With an Analysis of Current Practices in Java'. Delft University of Technology.

Munasinghe, Mohan. 2007. Making Development More Sustainable: Sustainomics Framework. USA: MIND Press.

Norberg-Schulz, Christian. 1991. Genius Loci: Toward a Phenomenology of Architecture. Rizzoli International Publication Inc.

Norberg Schulz, Christian. 1965. 'Intentions in Architecture'. The MIT Press.

Purbadi, Yohanes Djarot, and Reginaldo Christophori Lake. 2019. 'Konsep KampungWisata Sejahtera, Kreatif, Cerdas Dan Lestari Berkelanjutan'. EMARA: Indonesian Journal of Architecture 5 (1): 12-23. https://doi.org/10.29080/eija.v5i1.641.

Schefold, Reimar, Gaudenz Domenig, and Peter J.M. Nas. 2004. 'Indonesian Houses: Tradition and Transformation in Vernacular Architecture'. In Indonesian Houses: Tradition and Transformation in Vernacular
Architecture, edited by Reimar Schefold, P. Nas, and Gaudenz Domenig. Singapore: NUS Press.

Setiawan, Emily, and Rumiati Rosaline Tobing. 2019. 'Bentukan Arsitektur Permukiman Desa Tradisional Batak Toba Sebagai Pendukung Pariwisata, Obyek Studi: Desa Adat Ragi Hotang Meat, Kabupaten Toba Samosir'. Bandung.

Setiawan, Taufiqurrahman. 2010. 'Bentuk Adaptasi Lingkungan Pada Permukiman Tradisional Di Danau Toba'. Berkala Arkeologi Sangkhakala 13 (25): 145-53. https://doi.org/https://doi.org/10.24832/bas.v $13 i 25.196$.

Siahaan, Fanny. 2017. 'Identifikasi Aplikasi Arsitektur Biologis Pada Rumah Tradisional Batak Toba Di Sumatera Utara, Indonesia'. In Prosiding Seminar Kearifan Lokal Dan Lingkungan Binaan, 125-44.

Subroto, Tarcicius Yoyok Wahyu. 2019. 'Koeksistensi Alam Dan Budaya Dalam Arsitektur'. ARTEKS: Jurnal Teknik Arsitektur 3 (2). https://doi.org/10.30822/arteks.v3i2.60.

Sudarwani, Margareta Maria, and Iwan Priyoga. 2019. 'Toba Batak House of Huta Bagasan in Jangga Dolog Village'. ARSITEKTURA 17 (1): 109. https://doi.org/10.20961/arst.v17i1.29356.

Thakkar, Urvi. 2019. 'Gen Z Dan Masa Depan Dari Wisata Berkelanjutan'. Booking.Com. 2019.

Tobing, Rumiati Rosaline, and Grace Mananda Hutabarat. 2019. 'The Traditional Settlement Architecture of the Bataknese Toba Tribe and Clan Kinship in the Village of Hutaginjang, North Sumatera, Indonesia'. ISVS E-Journal 6 (2): 12-21.

Tobing, Rumiati Rosaline, and Christin Purnamasari. 2019. 'Perubahan Arsitektur Permukimn Tradisional Batak Toba Akibat Pengaruh Modernisasi, Obyek Studi: Huta Siallagan Samosir'. Bandung.

Tobing, Rumiati Rosaline, Andi Kumala Sakti, and Hanny. 2020. 'Kajian Arsitektur Berkelanjutan Pada Geosite Huta Siallagan Sebagai Desa Wisata Budaya'. Bandung.

Widodo, Johannes. 2019. 'Human, Nature, And Architecture'. ARTEKS: Jurnal Teknik Arsitektur 3 (2): 145-48. https://doi.org/10.30822/arteks.v3i2.65. 